\title{
Demanda de amparo indirecto presentada a través del portal de servicios en línea del poder judicial de la federación. procede desecharla de plano cuando carece de la firma electrónica del quejoso.
}

Décima Época Registro: 2019715 Instancia: Pleno, Jurisprudencia Semanario de la Federación 26 de abril de 2019 P./J. 8/2019 (10a.)

El artículo 3o. de la Ley de Amparo establece la posibilidad de actuar ante el Poder Judicial de la Federación mediante el empleo de las tecnologías de la información utilizando una firma electrónica, cuya regulación se encomendó al Consejo de la Judicatura Federal, órgano que actuando con la Suprema Corte de Justicia de la Nación y el Tribunal Electoral del Poder Judicial de la Federación, expidió los Acuerdos Generales Conjuntos Número 1/2013 y 1/2015, de los que se advierte, en suma, que la Firma Electrónica Certificada del Poder Judicial de la Federación (FIREL), es equiparable a un documento de identidad, al ser el instrumento a través del cual se ingresa al sistema electrónico para actuar en los asuntos de la competencia de la Suprema Corte, del Tribunal Electoral, de los Tribunales de Circuito y de los Juzgados de Distrito, con los mismos efectos jurídicos de la firma autógrafa; de suerte que la posibilidad de presentar una demanda de amparo por vía electrónica no implicó soslayar el principio de "instancia de parte agraviada" previsto en los artículos 107, fracción I, de la Constitución Política de los Estados Unidos Mexicanos y 6o. de la Ley de Amparo, sino que únicamente tuvo como objetivos fundamentales, entre otros, simplificar la actuación procesal de los órganos jurisdiccionales y modernizar el sistema de impartición de justicia otorgando validez a las promociones judiciales realizadas a través de medios digitales usando la FIREL. En consecuencia, debe desecharse de plano la demanda de amparo indirecto presentada por vía electrónica cuando carezca de la FIREL del quejoso, porque la falta de la firma electrónica de quien promueve 
el amparo no puede equipararse a una irregularidad subsanable a través de la prevención a que hace alusión el artículo 114 de la Ley de Amparo, sino que se trata del incumplimiento de uno de los principios rectores del juicio de amparo que no amerita prevención alguna, como sucede ante la falta de la firma autógrafa de una demanda de amparo presentada de forma ordinaria. Cabe señalar que este criterio resulta inaplicable tratándose del supuesto expreso del artículo 109 de la Ley de Amparo, conforme al cual será innecesaria la firma electrónica cuando el juicio de amparo se promueva con fundamento en el artículo 15 de la ley referida. 